Универзитет у Новом Саду, Филозофрски факултет, Нови Сад; Висока школа струковних студија за образовање васпитача, Нови Сад

DOI 10.5937/kultura1651013M

УДК 640.43:316.7

640.43:316.728

оригиналан научни рад

\title{
TPETAMECTA:
}

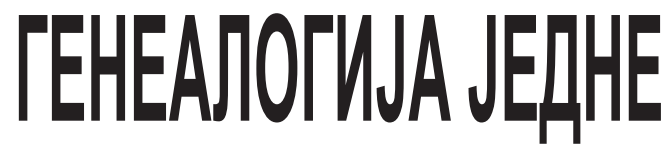
XEETPOTOONJE

\section{ГРАБАНСКОГ АРУШТВА}

\begin{abstract}
Сажетак: Предмет истраживања у овом раду су кафане као трећа места, која су дефинисана из угла соииолошко-генеалошког приступа. Генеалогија је предложена као теоријско-методолошки оквир истраживања, односно као спацијална историја места̂. 3 датак такве генеалогије је да истражи спаиијализаиију једног типа друштвености и соиијалног капитала грађанског друштва. У раду је назначен и иири друштвено-историјски амбијент, у којем се друштвена улога и значај трећих места огледао кроз нихов допринос у процесима формирања нових облика друштвености и јавног резоновања уопите. Историјски успон кафана је у раду контекстуализован: у оквире појаве новог типа критичке јавности у односу на стару репрезентативну; у оквире процеса одвајања приватне и јавне сфере; и као једна врста до краја неиздиференцираног простора, прекида и хетеротопије, која у соиијалној географији грађанских друштава стоји насупрот постојећој сталешкој диферениијаиији и будућој просторно-класној сегрегаиији. У закључку рада је истакнуто да, упркос томе што су трећа места била повлатћени друштвени простори, она нису једина и фундаментална места генезе рачионалног дискурса. Па ипак, трећа места имају кључни значај у прочесима формирања урбаних институтаิ, образовања јавног простора, јавног говора, грађанских слобода и легитимаиије рационалности у друштвима Западне Европе.
\end{abstract}


Кључне речи: трећа места, кафана, дискурс, генеалогија, хетеротопија

\section{$y_{80 \partial}$}

Данас су кафане безупитни део сценографије свакодневног живота. Њихово присуство у јавном простору не промиче погледима пролазника, странаца, породица, обичних људи у њиховој свакодневици. На њих смо навикли као на постојану институционалну позадину наше свакодневице, те се свако научно питање, полемика или проблематизација која покушава да види или открије нешто још непримећено и несазнато, чини сувишном, непотребном свакодневном здравом разуму. Јер, у кафане се једноставно навраћа, долази, поред њих се пролази, оне се избегавају или препоручују, оне су уточишта и прибежишта исто колико и сумњива места. Оне су постале део обичајности и безупитне ритуалности већине људи. Кафане су неизбежни део динамике свакодневног живота глобализованог друштва. Већ одавно не постоји ограничена регионална географија кафана омеђена само једним типом друштва, политике, културе, начином живота: „коначно, чак и након опадања енглеских кафетерија ${ }^{1}$, оне су се проширили свугде - Рим, Париз, Беч, Бостон"2. Навикнути смо на динамику њиховог брзог ницања исто колико и брзог гашења; све су ређе оне које су део традиције дугог трајања и дугог памћења; оне које су микрогеографски, просторно-урбани, културно-историјски и друштвени оквири вишегенерацијског колективног памћења и сећања - но, таквих још увек има и нека будућа историјска и социолошка истраживања треба да им посвете пажњу. ${ }^{3}$

Мало ко данас у кафанама открива дужу и дубљу културну историју једне епохе и једне друштвене географије - Модерне и Европе. Мали је број оних који ће своја истраживања великих места политичког, друштвеног, културног и економског живота: тржишта, универзитете, породицу,

1 Coffeehouse у традиционалном смислу речи (кафетерија), за разлику од alehouse, inn или tavern. У овом раду се неће правити разлике између различитих варијетета кафана као трећих места (таверне, пивнице, кафетерије), изузев у оним случајевима када се буде говорило о традиционалним енглеским кафетеријама (coffeehouse). Оно што је важније од различитих варијетета кафана јесте да је ,talking/drinking синергизам заједнички пабовима, тавернама, бистроима, салонима, остеријама - како год их називали и где год их затекли" (Oldenburg, 1989, p. 167).

2 Zappiah, N. (2007) Coffeehouses and Culture, Huntington Library Quarterly, 70 (4), p. 671-677.

3 Важан допринос оваквом концепту истраживања кафана дао је код нас Драгољуб Брка Ђорђевић својим истраживањима (Ђорђевић, 2011; Ђорђевић, 2012). 
знање, моћ, власт, вредности, норме, регулације, заменити „малим”, „обичним”, понекад „сумњивим” местима као што су то кафане. Али нешто смо научлили од аналиста: од Бродела ${ }^{4}$ да једна географија (Медитеран) има своју историчност; да свакидашњица нема само своју структуру, већ и своју историчност ${ }^{5}$. Нешто смо научили од интеракциониста, социјалних драматурга и етнометодолога: не постоје безупитне ствари, места, простори, догађаји, сусрети. Дуго времена је требало социологији да као значајни и легитимни предмет својих анализа дефинише „обичан” људски сусрет, наше свакодневне маске, изгледе и манире лизу свакодневице и интеракцијског поретка у издвојеним и забрањеним просторима - тамо где је социологија дуго времена мислила да је једини поредак онај наметнут строгим кућним редом ${ }^{7}$. За социологију нема свршених или малих тема; нема коначности у друштвеној, културној, политичкој и историјској динамици. Нешто смо научили од Фукоа: увести у легитимну анализу „забрањене” просторе и теме: луднице, затворе, јавна погубљења, сексуалност, породични живот. Управо су Гофманова социјална драматургија и етнометодологија, као и Фукоова истраживања малих светова̂ и различитих микрофизика̂ (моћи, знања, простора), понудила увиде у теоријске значајности друштвених разлика̂ малих интензитета̂. Јер бити културно маргинализован, политички искључен или статистички занемарљив још увек не значи бити истраживачки безначајан. Напротив, како пише Тим Кресвел (Tim Cresswell), „маргинални, гротескни, необични елементи и догађаји у друштву интересантни су сами по себи, али они постају још више интересантнији када истражимо њихову улогу у дефинисању 'нормалног', класичног, доминантног. Центар не може да постоји без маргине"в. Питер Стелибрас (Peter Stallybrass) и Елон Вајт (Allon White) такође су тврдили да оно што је друштвено периферно често је симболички централно․ Можда и најважније: научили

4 Brodel, F. (2001) Mediteran i mediteranski svet u doba Filipa II (tom I), Beo$\mathrm{grad} /$ Podgorica: Geopoetika.

5 Braudel, F. (1992) Struktura svakidašnjice: materijalna civilizacija, ekonomija i kapitalizam od 15. do 18. stoljeća, Zagreb: August Cesarec.

6 Gofman, E. (2000) Kako se predstavljamo u svakodnevnom životu, Beograd: Geopoetika.

7 Gofman, E. (2011) Azili, Novi Sad: Mediterran Publishing.

8 Cresswell, T. (1996) In Place/Out of Place: Geography, Ideology and Transgression, Minneapolis: University of Minnesota Press, p. 149.

9 Stallybrass, P. and White, A. (1986) The Politics and Poetics of Transgression, Ithaca, N.Y.: Cornell University Press. 
смо „да је све сингуларно у универзалној историји”10 - да je (једино) могуће пратити генеалогије сингуларности, а не велике тотализујуће историје. Од Аријеса и Дибија ${ }^{11}$ научили смо да у историјско-социолошку анализу треба увести детињство, приватни живот, вртове, библиотеке, скровита места, приватна писма, исповести, писменост, интиму, усамљену доколицу, путовања. Још једном, научио је то Фуко од Ничеа: много тога још заслужује да уђе у токове генеалошких анализа, много тога што данас још не можемо да урадимо. Дуго је времена требало да се охрабримо за историју старости ${ }^{12}$, још више је храбрости требало за историју самоубистава $^{13}$, историју тела - још ненаписану; још више ће храбрости требати за историју храбрости, љубави: „До сада све оно што је постојању давало неку боју није још имало историју: или где би било историје љубави, грамзивости, зависти, савести, пијетета, окрутности?”14. Та „мала” сива историја - генеалогија ${ }^{15}$ - историја „малих” простора и места, каква је кафана, треба да се послужи генеалогијом као методологијом, као што је то урађено са рођењем затвора $^{16}$ или историјом сексуалности ${ }^{17}$. „Претпоставимо да смо се подухватили писања историје љубави или сексуалности кроз векове. Могли бисмо да будемо задовољни својим радом када бисмо стигли до тачке у којој би читалац могао да сазна какве су биле варијације мисли и пракса пагана, или пак хришћана, на тако познату тему као што је секс... Наједном нам пукне пред очима; чим се варијација појасни до краја, вечна тема се брише, а на њеном месту сада се налазе само међусобно различите варијације, које су се низале једна за другом"18.

10 Ven, P. (2014) Fuko: kao mislilac i kao čovek, Novi Sad: Mediterran Publishing, str. 15.

11 Аријес, Ф. и Диби, Ж. (2002) Историја приватног живота (3), Београд: Clio; Аријес, Ф. и Диби, Ж. (2003) Историја приватног живота (4), Београд: Clio.

12 Minoa, Ž. (1994) Istorija starosti: od antike do renesanse, Novi Sad: Izdavačka knjižarnica Zorana Stojanovića.

13 Minoa, Ž. (2008) Istorija samoubistava, Novi Sad: Mediterran Publishing.

14 Niče, F. (1984) Vesela nauka, Beograd: Grafos, str. 45-46.

15 Fuko, M. (2010a) Niče, genealogija, istorija, u: Mišel Fuko: Spisi i razgovori Kozomara, M. (ur.), Beograd: Fedon, cтр. 59-88.

16 Фуко, М. (1997) Надзирати и кажњавати: настанак затвора, Нови Сад: Издавачка књижарница Зорана Стојановића.

17 Fuko, M. (2006) Volja za znanjem: istorija seksualnosti I, Loznica: Karpos.

18 Ven, P. (2014) Fuko: kao mislilac i kao čovek, Novi Sad: Mediterran Publishing, str. 18. 


\section{Генеалогија као методологија: ревизија устаљених представа}

Увести у социолошко-генеалошку анализу кафану као треће место неминовно намеће проблем меандрирања генеалошких токова сингуларности, јер уместо једне, појављује се мноштво повезаних тачака. Другим речима, полазећи од кафане, стижемо до капитализма, либерализма, просветитељства, рестаурације, урбанизације, демографских промена, технолошких скокова, промена просторног уређења, естетике, структуре свакидашњице, јавности, медија, дискурса, идеологије, буржоазије, породице, агроекономије житарица, грожђа, кафе, чаја, пива и вина - до конјунктуpe и динамике, осцилација, нестабилности, флуктуација. Но ипак, сабирање расутих сингуларности и различитих културних и друштвених варијација око генеалогије кафана у неколико пресудних тачака, поново затвара круг истим питањем: Ко смо ми у нашем времену? Али и ко смо ми у нашем простору? Ко смо ми у нашем говору - заробљени у сопствену гео-епистемологију ${ }^{19}$. У простору и географији модерне, рационалне, дискурзивно опосредоване јавности која је неодвојива од трећих места која, не мање од других, „фундаменталнијих” социјализаторских институција, посредују између појединца и глобалног друштва. Јер, генеалогија трећих места није само мала, сива временска линија развоја једне сингуларности. То је истовремено и генеалогија простора и места̂. Управо једна таква опросторена, спацијализована историја места̂ могућа је као генеалогија. Али просторност ничеанском сивилу генеалогије почиње да даје боје, мирисе, укусе, покрете, динамику и драматургију. Фукоу су, чини се, управо простор и географија омогућиле геналошке анализе оних великих тема: дисциплине, надзора, кажњавања, моћи, сексуалности, лудила. Када је приморан да констатује: „географија мора да буде у срцу онога чиме се бавим"20, он није више само генеалог ничеанац, већ ничеанац географ. Јер „испитујући географију, срели смо се са извесним бројем појмова: знање, моћ, наука, дискурзивна формација, поглед, епистема..."21. Зар не отвара питање дисциплине и надзора врата казнионица, касарни, интерната? Зар нас јауци и жамор не воде до трга где се обавља

19 Маринковић, Д., Шљукић, С. и Ристић, Д. (2014) Од генеалогије ка гео-епистемологији: заокрет ка локалности простора, времена и знања, Социолошки преглед, 48(3), стр. 333-352.

20 Fuko, M. (2010a) Niče, genealogija, istorija, u: Mišel Fuko: Spisi i razgovori Kozomara, M. (ur.), Beograd: Fedon, str. 59-88.

21 Исто, стр. 69. 
церемонијал јавног сакаћења тела и погубљење 22 ? Зар нас питање моћи не уводи у археолошке слојеве знања? ${ }^{23}$ Куга нас уводи у дисциплинарни модел зараженог града; губа у просторе трајне изолације, изопштености, у азил ${ }^{24}$. Зар нас Историја сексуалности не уводи у куће и станове? У просторни распоред, до граница постављених између родитељске и дечје собе. Не, фукоовска историја сексуалности није воајерско вирење кроз кључаоницу родитељске собе где се одвија легитимна, продуктивна, прокреативна сексуалност. Пре је то утврђивање просторних диспозиција, односа, микрогеографија. Таква генеалогија простора и места треба да буде методолошки нацрт и за истраживање трећих места̂. Када отворимо врата кафана, закорачили смо у генеалогију једне просторности - у генеалогију просторности једног типа друштвености који је постао социјални капитал грађанског друштва и њене критичке јавности. То је истовремено оно што је социологија научила од Зимела: да постоје типови чисте друштвености, оне која је прочишћена од других намера или циљева, ослобођена строгости улога и друштвених положаја ${ }^{25}$, односно да су места симболички идентификатори простора, захваљујући којима стварамо сопствене идентитете и представе о друштвеним односима: „Простор није само услов, него је и симбол односа према људима"26.

Када се отворе врата кафана мора се, методолошки, баш као што је то радио велики Архивар, осликати просторност тог типа друштвености и таквог социјалног капитала. То је методологија осликавања на подлози генеалошких анализа ${ }^{27}$. Али већ смо раније кренули од осликаног2 ${ }^{28}$ пратећи историјске прелазе од Веласкезових Младих племкиња до Монеовог Бара у Фолибержеру и Дегаове Чаше апсинта. Већ тада је била назначена једна имплицитна - географија. „Мадрид и Шпанија на једној, Париз и Француска на другој страни.

22 Фуко, М. (1997) Надзирати и кажнавати: настанак затвора, Нови Сад: Издавачка књижарница Зорана Стојановића.

23 Fuko, M. (1998) Arheologija znanja, Beograd: Plato.

24 Fuko, M. (2014a) Bezbednost, teritorija, stanovništvo, Novi Sad: Mediterran Publishing.

25 Simmel, G. (1971) Sociability, in: Georg Simmel: On Individuality and Social Forms, Levine Donald, N. (ed.) (Selected Writings), p. 127-140. Chicago and London: University of Chicago Press, pp. 129, 132, 137.

26 Zimel, G. (2008) Georg Zimel 1858-2008, (prir.) Marinković, D., Novi Sad: Mediterran Publishing i VSA, str. 154.

27 Delez, Ž. (1989) Fuko, Novi Sad: Izdavačka knjižarnica Zorana Stojanovića, str. 29.

28 Marinković, D. Ideologija, javnost i rođenje „trećih mesta”, u: Nacrt za sociologiju ideologije, Marinković, D. i Ristić, D. (2013), Novi Sad: Mediterran Publishing, str. 147-167. 
Раздваја их политички и друштвени поредак: краљевство Филипа IV на једној, Трећа република на другој страни. Свакако, дели их и стил: шпански је барок код Дијега Веласкеза у потрази за светлом. Импресионизам се још увек бори за сопствену изражајну аутентичност. Едвард Мане се диви Веласкезу, али он неће само светлост. Он хоће да боји мрље. Шта је код Манеа радња? Огромна блистава позадина кафане која се рефлектује или конобарица? Одсутност њеног погледа и доминација позадине угрожавају поредак тродимензионалности. Као да доминација кафане која се назире у огледалу лишава конобарииу да учествује у животу слике, у животу кафане ${ }^{29}$. Чашу апсинта узећемо за наставак претходне слике, за наставак кафане. То је оно што је сада десно од конобарице, али негде у самом дну, близу врата која само лабаво деле улицу и кафану. Вероватно је то пар, љубавници, познаници, супружници? Али иста је одсутност погледа присутна ${ }^{30}$. Међутим, све три слике и Веласкезову, и Манеову и Дегаову повезује иста позадина. То је огледало: у којем се рефлектује распад старог режима у Младим племкињама; то је кафана пуна људи и жамор, разговори који се виде у огледалу иза ћутљиве конобарице. Коначно, то је прозор, стакло иза пара који пије апсинт. Прозор који дели улицу и кафану само танким завесама. Дакле, Мане и Дега су нас натерали да видимо оно невидљиво, ненасликано, неизречено до краја. Натерали су нас изван слике - изван насликаног, у много шири простор - у простор јавног и дискурзивно-идеолошког. То је простор без којег епоха модерне не би могла да живи"

Овоме треба додати не само појединачну већ, може се рећи, колективну заинтересованост једног покрета за питање кафанских простора. И пре него што је омеђен теоријски и тематски социолошки простор бављења кафанама, од Хабермаса до Олденбурга, од јавног резоновања приватних људи до социјалног капитала трећих места, све смо то могли да затекнемо већ забележено, насликано. То нису само Мане и Дега, то су: Анри Евенепоел (Henri Evenepoel) и његова Le Café d'Harcourt a Paris (1897), Гистав Кајебот (Gustave Caillebotte) и At the Café (1880), Ернст Лудвиг Кирхнер (Ernst Ludwig Kirchner) и The Garden Café (1914), Данијел Васкез

29 Janson, H. W. (1970) Istorija umetnosti, Beograd: Jugoslavija, str. 493.

30 Haine, S.W. (1992) Café Friend: Friendship and Fraternity in Parisian Working-Class Cafes, 1850-1914, Journal of Contemporary History, 27(4) p. 609.

31 Marinković, D. Ideologija, javnost i rođenje „trećih mesta”, u: Nacrt za sociologiju ideologije, Marinković, D. i Ristić, D. (2013), Novi Sad: Mediterran Publishing, str. 147-167. 
Дијаз (Daniel Vásquez Díaz) и Café de Paris (1909), Дијего Ривера (Diego Rivera) и Table on a Café Terrace (1915), Исак Израел (Isaac Lazarus Israëls) и At The Coffee Shop (1934), Алфред Анри Маурер (Alfred Henry Maurer) и In a Cafe (1905) и други. Неки будући рад легитимно би могао да се бави само социолошком анализом импресионистичке заинтересованости за тему кафана, али у оквиру овог рада насликани живот кафана служи као илустрација за оно што бисмо могли да назовемо великим историјским сударом два поретка, умирућег старог и рађајућег новог. У том судару пуном дисконтинуитета̂ настајало је и развијало се треће место. Јер деветнаестовековни импресионизам насликао је кафане као већ довршену друштвену и историјску сценографију, као оно што је саморазумљива и безупитна свакодневица урбаног живота, а заправо, генеалогија се смешта у веома колебљиву историју ранијег поретка.

Као и импресионисти деветнаестог века, навикнути смо да видимо кафане смештене у средиштима градова, у удобној сценографији урбане доколице, динамике трговине, мноштва људских сусрета, мешавине култура, стилова, израза, слободе јавног говора. Но та сценографија удобности и доколице се слама оног тренутка када се закорачи у системске и структурне нестабилности седамнаестог и осамнаестог века. Јер „с 18. веком...у Европи слама се биолошки Стари поредак, скуп присила, запрека, структура, односа, нумеричких игри, које су до тада биле нормом"32. Генеалогија трећих места није - колико год желели импресионистичким колоритом да их осликамо - смештена једино у друштвеноисторијски и политички амбијент слободе, једнакости, чисте зимеловске друштвености, комуникативности, хабермасовског јавног резоновања у coffee-houses и Tischgesellschaf$t^{33}$. Шири историјски амбијент њихове генеалогије био је другачији. С једне стране, друштвено-политички амбијент настанка кафана као значајних трећих места ${ }^{34}$ још увек припада Старом режиму исто колико и старом биолошком поретку о коме говори Бродел. У том смислу Кован је спреман да коригује Хабермасову хипотезу и да констатује како „успон кафе није инаугурисао 'стварање модерног света'; кафа и кафане су прихваћене и популаризоване од стране

32 Braudel, F. (1992) Struktura svakidašnjice: materijalna civilizacija, ekonomija i kapitalizam od 15. do 18. stoljeća, Zagreb: August Cesarec, str. 64.

33 Habermas, J. (2012) Javno mnjenje - istraživanje u oblasti jedne kategorije građanskog društva, Novi Sad: Mediterran Publishing, str. 84.

34 Уместо Мидових значајних других, кафана може да се означи као значајни трећи. 
Старог режима и прединдустријског друштва" ${ }^{35}$. Ово за собом повлачи кориговање још једне важне претпоставке: „Да ли семе модернитета лежи у још-не-модерној кафетерији (coffeehouse)?"36. Доминантна хипотеза о улози трећих места као простора у којима се сусрећу нови тип друштвености и рационалности, јавне критике и слободног говора, литерарне јавности и јавног резоновања више је била нормативна него емпиријска и практична ${ }^{37}$ чињеница: „Оно што смо пронашли као Хабермасову трезвеност, рационалност, сферу приватних људи окупљених заједно да испробају свој разум у јавности. Али било је тешко то пронаћи у стварним кафанама [Лондона]"38. Наравно, овим се не оспорава нити умањује једна од централних хипотеза о улози кафана као трећих места у изградњи модерне рационалности, критичке јавности и јавног резоновања. Ови налази више служе као корективни фактори који штите од идеализације историјских ситуација. С друге стране, настанак кафана још увек је смештен у стари биолошки поредак репродукције и производње хране. Када кафане на европском тлу, пре свега на Западу, доживљавају свој успон још не може да се наслути слом старог (биолошког) поретка у којем „све води ка равнотежи"з9. Залазак тог поретка старог типа равнотеже је близу, али он још не може да се наслути, те као што средњи век не зна да је средњи, не зна у односу на чега би био $y$ средини, тако и стари биолошки поредак још увек не може да наслути долазак дугорочних структурних неравнотежа и великих осцилација - мада су оне близу управо када кафане доживљавају свој успон.

35 Cowan, B. (2005) The Social Life of Coffee: The Emergence of the British Coffeehouse, New Haven \& London: Yale University Press, p. 3; Zappiah, N. (2007) Coffeehouses and Culture, Huntington Library Quarterly, 70 (4), p. 672.

36 Zappiah, N. (2007) Coffeehouses and Culture, Huntington Library Quarterly, 70 (4), p. 672.

37 Кован је у праву да у истраживању односа кафана и јавне сфере треба разликовати нормативну и практичну димензију: „Биће корисно у овој дискусији направити разлику између онога што ћу назвати нормативном и практичном јавном свефом. Разлике између ове две су разлике између мишљења и делања, или боље између прескриптивног друштвеног 'требања' и дескриптивног 'јесте'...Нормативна јавна сфера се састоји од идеала акције и понашања која су задобијена у јавној сфери, док практична јавна сфера треба да се разуме као збрка свакодневне реалности јавног живота" (Cowan, B. (2001) What Was Masculine about the Public Sphere? Gender and the Coffeehouse Milieu in Post-Restoration England, History Workshop Journal 51, p. 133).

38 Исто, стр. 142.

39 Braudel, F. (1992) Struktura svakidašnjice: materijalna civilizacija, ekonomija i kapitalizam od 15. do 18. stoljeća, Zagreb: August Cesarec, str. 64. 
Стари биолошки поредак није био само питање демографске равнотеже наталитета и морталитета. Стварну игру бројки, како демографских, тако и економских, свих оних који чине материјалну основу старог биолошког поретка, никада нећемо поуздано знати. То су „бројке које ваља измислити"40. Док се не стигне до колорита импресионистичке слике кафана, њихова генеалогија смештена је заиста у сивило које је много пута ближе тамној него светлој нијанси. Јер равнотежа о којој говори Бродел, само је део игре периодичности. Дакле, успон кафана и свега онога што видимо као њихову непосредну везу са модерном, са израстањем новог типа критичке литерарне јавности у односу на стару репрезентативну; њихову непосредну везу са спацијализацијом једног новог типа „поравнате”, „изнивелисане” друштвености; њихову везу са концептом демократије, слободе и политике, све је то у почетку смештено усред многих осцилација и периодичности, усред структурних несигурности и неизвесности, сталних колебљивости. Градски живот који данас не можемо да замислимо без кафана тада је још увек полу-руралан. Градска економија још увек више зависи од локалних атара, а мање од међународне трговине. Урбаност седамнаестог и осамнаестог века још је веома фрагилни друштвени, културни, економски и демографски сценарио. Сваки демографски раст је само тренутак у општој нестабилности, јер је равнотежа старог биолошког поретка обезбеђена високом стопом морталитета, а не само наталитета. Умирања периодично нивелишу нараслу популацију која не може да се прехрани: „између два покрета рађања и умирања започиње бескрајна игра" ${ }^{41}$. Ако равнотежа и постоји, онда се она односи на сталност успона и падова јер једино се „они правилно измењују и допуњују”42.

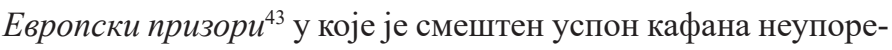
диво су ближи фукоовској драматургији куге, губе, окрутности казнених поступака, глади, лутања лудака, епидемија и болести, него хабермасовској рационалности и трезвености. Посебно је још далеко импресионистичка представа урбане кафанске раскалашности и доколице. Често заборављамо да су и раскошна ренесанса, али и каснији барок, рођени усред велике болести - куге; усред глади, оскудности и скромности која је начин живота целокупног Медитерана ${ }^{44}$,

\footnotetext{
40 Исто, стр. 20.

41 Исто, стр. 64.

42 Исто, стр. 67.

43 Исто, стр. 70.

44 Brodel, F. (2001) Mediteran i mediteranski svet u doba Filipa II (I), Beograd/ Podgorica: Geopoetika, str. 57, 135.
} 
па и оног удаљенијег Медитерана који се прелива преко планинских ланаца који су наборани над његовим обалама. Тело у ренесанси дубоко је засечено великом смртношћу и нехигијеном појединаца, читавих породица и градова; засечено болестима и још неразвијеном медицином; засечено најездама са истока и југа, политичким нестабилностима и локалним обрачунима и ратовима. Европа је, чини се, више од разних врста несрећа, него од благостања, правила своја знања и идентитет: од болести, куге, губе, јереси, ратова, прогона, најезда, упада. Од ратова - технологију, тактике, стратегије, територије, географију, картографију и мапе као инструменте знања/моћй ну, надзор, дисциплину, тело; од упада и најезди - антропологију, знања о другоме и страном; од јереси - инквизицију, исповести и признања, поступке мере, истраге, испитивања; од покајања - аналитику вербалног признања $a^{46}$; од прогона - затвор и гето; од губе - бинарну поделу, одвајање, геоепистемологију азила; од куге - гео-епистемологију контроле, надзора, пракси класификовања; од нехигијене - популацију, полищију: „Није могуће видети европску историју као прогресивно отелотворење велике уједињујуће идеје, јер су идеје саме производ историје... Европска идеја била је више производ конфликта, него консензуса" ${ }^{47}$. Европски идентитет и знање више су рођени кроз репресивну хипотезу ${ }^{48}$. И пре него што ће се током класицистичког раздобља генерализовати у дискурсе, знања и праксе истине - преко инквизиторског епистемолошког триједра мере-истраге-испитивања (mesure-enquête-examen) ${ }^{49}$ - које производе идентитет субјективитета, раносредњовековним менталитетом влада cmpax и грех ${ }^{50}$. Ако је нешто заједничко тој расутој популацији (мада то није популација у правом смислу речи), размештеној (мада не плански) или пре расутој по још нејасној географији - то је cmpax. Без обзира на неповезану локалност и расуту парохијалност, заједнички идентитет је идентитет

45 Fuko, M. (2012a) Pitanja Mišelu Fukou o geografiji, u: Mišel Fuko, Moć/znanje: odabrani spisi i razgovori 1972-1977, Novi Sad: Mediterran Publishing, str. 69-82.

46 Foucault, M. Du gouvemement des vivants, in: Dits et écrits (1980-1988, IV), (eds.) Defert, D. and Ewald, F. (1994a), Paris: Gallimard, p. 125-129.

47 Delanty, G. (1995) Inventing Europe: Idea, Identity, Reality, London: Macmillan Press, p. 2.

48 Fuko, M. (2006) Volja za znanjem: istorija seksualnosti I, Loznica: Karpos.

49 Foucault, M. Théories et institutions pénales, in: Dits et écrits (1980-1988, IV), (eds.) Defert, D. and Ewald, F. (1994b), p. 389-393, Paris: Gallimard, p. 390; Fuko, M. (1990) Predavanja, Novi Sad: Svetovi, str. 18.

50 Delimo, Ž. (1987) Strah na Zapadu, Novi Sad: Izdavačka knjižarnica Zorana Stojanovića. 
страха. То је „Европа” страха ${ }^{51}$, то је опседнути менталитет/ идентитет. У веома честим циклусима влада страх од најезди, које недозвољавају да се устали предвидљива драматургија свакодневице. Тај менталитет је опседнут страхом од јереси; страхом од инквизиције; страхом од куге; страхом од сопствених пожуда; страхом од сопствених тела као места жеља̂; страхом од мрака; од греха, чистилишта, пакла, од ломача на којима горе или људи или књиге - на којима се спаљују, управо по узору на пакао, недопуштена знања (Index Librorum Prohibitorum). Страхом од упада других, варвара ${ }^{52}$ - од оних чију етничку, културну, језичку, религијску разноликост често назива једним именом: Сарацени, Персијанци, Азијати, Турци. Ту европски номинализам прелази у „,реализам” других. Страх и каснија политика страха, режими страха, учествоваће у обликовању субјекта/идентитета који до себе долази преко рефлексије признања и исповести ${ }^{53}$. То је субјекат који признаје - у исповедаоници; на тргу, у истражним поступцима инквизиције, у Исповестима, у Писмима, у Разговорима; то је идентитет „полиције исказа" ${ }^{54}$. Наш је идентитет израњао заједно са дискурсима и знањима; заједно са репресивним праксама и дискурсима који су легитимисали контролу и надзор. У том смислу, идентитет јесте питање борбе и отпора, али не оне врсте борбе у ослобођеном простору у којима се избор намеће као борба (борба око избора), већ питање борби са ућуткивањима, надзорима, репресалијама, страхом. Идентитет је тако постао питање и исповести и интернализоване принудности која од нас не тражи само да кажемо какви смо, већ и ко смо - на основу онога што чинимо: „Најзад, све актуелне борбе врте се око истог питања: ко смо ми?" ${ }^{55}$.

$M u$ - трезвени критичари; ми рационални субјекти јавног простора; ми - спремни да слободно изговоримо своје мишљење; ми - мигранти из првих и других у трећа места, одбегли у кафане од својих породица, од погледа жена, од надзора својих послодаваца, још више од строгих моралистичких погледа и придика локалних пароха и цркве; ми - „поравнати” у прочишћеној друштвености на трећим местима са својим претпостављенима, са онима богатијим или сиромашнијим од нас - рођени смо на размеђи, на

51 Le Gof, Ž. (2010) Da li je Evropa stvorena u srednjem veku, Beograd: Clio.

52 Todorov, C. (2010) Strah od varvara, Loznica: Karpos.

53 Fuko, M. (2014b) Tehnologije sopstva, Loznica: Karpos.

54 Fuko, M. (2006) Volja za znanjem: istorija seksualnosti I, Loznica: Karpos, str. 23.

55 Fuko, M. Dva ogleda o subjektu i moći, u: Mišel Fuko: Spisi i razgovori, Kozomara, M. (ur.) (2010b), Beograd: Fedon, str. 384-411. 
границама: између слободе и надзора, између јавног погубљења и самоће затвора, између критичког и репрезентативног, између села и града, између системских оскудица и структурних продуктивности капитализма, између старе хобсовске немани и новог бентамовског принципа свеприсутног погледа, између географије локалности и географије нових груписања и централизације, између старе споре и нове брзе географије ${ }^{56}$. То нас непосредно уводи у тему граница (просторних и временских), међа, хетеротопија, микро-географије, микро-картографије родних, политичких и друштвено произведених простора ${ }^{57}$, те коначно генеалогије преображаја простора у којој су трећа места рођена. Таква генеалогија је битно питање (нове) спацијализације говора, један облик историје који може да објасни конституисање знања и говора, без потребе упућивања ка субјекту који је трансценденталан у односу на поље догађаја у својој „испразној једнакости током историје ${ }^{958}$.

\section{Колебљивост границุа}

Филип Аријес је запазио да се „на крају средњег века [jow] живи у свету који није ни приватан ни јаван"59. Још нису издиференциране границе тих великих области будућег грађанског живота. Границе будућих раздвајања још су колебљиве, савитљиве, пропустљиве. Неприкосновеност буржоаске приватности којом ће се штитити породица, пре свега жене и деца, а потом и интимност дома и имовина, задобијена је новим поделама и разноликим облицима нових искључивања, да би се остварио идеал: „’'[Ж]ивот грађанина треба озидати зидом'. Наравно, зидом приватности"б0.

Постоји извесна парадоксалност у великом одвајању приватног и јавног када се упореде кафане и шири просторни контекст. Наиме, с једне стране, кафана се појављује на

56 Paasi, A. (2001) Europe as a Social Process and Discourse: Considerations of Place, Boundaries and Identity, European Urban and Regional Studies, 8(1), p. 7-28.

57 Lefebvre, H. (1997) The Production of Space, Oxford: Blackwell; Philo, C. (2003) Foucault's geography, in: Thinking Space, Crang, M. and Thrift, N. (eds), London: Routledge, p. 205-238; Philo, C. (2005) Sex, life, death, geography: fragmentary remarks inspired by 'Foucault's populations Geographies', Population, Space and Place, 11 (4), p. 325-333; Simonsen, K. (2005) Bodies, sensations, space and time: the contribution from Henri Lefebvre, Geografiska Annaler: Series B, Human Geography, 87 (1), p. 1-14.

58 Fuko, M. (2006) Volja za znanjem: istorija seksualnosti I, Loznica: Karpos.

59 Фоазил, М. Записи из приватности, у: Историја приватног живота (3), ур. Аријес, Ф. и Диби, Ж. (2002) Београд: Clio, стр. 297.

60 Кастан, Н. Јавно и појединачно, у: Историја приватног живота (3), Аријес, Ф. и Диби, Ж. (2002), Београд: Clio, стр. 364-390. 
измаку средњег века као простор друштвене хомогенизације хетерогених друштвених, економских и културних елемената; као до краја неиздиференциран простор који стоји насупрот постојећој сталешкој диференцијацији и будућој просторно-класној сегрегацији. С друге стране, шири урбани план раста и развоја европских градова све ће више следити османовску матрицу диференциијалне географије ${ }^{61}$ утискујући у простор растућу класну неједнакост и хетерогенизацију, јер „после Османа станови су се стеснили”б2. У том смислу, кафана израста у геналогији опште борбе за простор који се стварао у судару јавног и приватног, јер кафана није ни приватни простор породичног живота, нити је простор јавности у политичком смислу речи; она није ни улица ни трг, али се она без њих не може замислити.

Она је треће место у широј географији кључних урбаних института - улице и трга; стамбеног кварта и пословних четврти: „мало-помало, улица је постала област јавног”63. Она није ни парламент ни медиј, нити део јавног политичког живота у ужем смислу речи, али политички живот у ширем смислу не може се замислити без тог позадинског, стално присутног жамора о политици, друштву и јавности који се образовао у кафанама. Стога, иако се не може спорити (већ само мање или више кориговати) генерална хипотеза о значајној улози кафана у образовању јавног простора, јавног говора, грађанских слобода, дискурзивности и изоштравања политичке критике, интензивирање диференцијалне географије заправо је све више сужавало простор за легитимацију рационалности која се образовала у трећим местима. Она заиста јесу су била повлашћени друштвени простори у којима се генерисао рационални дискурс, али свакако ни једини, a ускоро ће се показати, нити фундаментални. У дискурзивној производњи различитих значења друштвеног света у којој су суспендоване класне разлике и прерогативи и моћ, у којој је једино било битно шта неко говори, а не ко говори, ${ }^{64}$ некада (релативно) монолитна значења света почела су да се фрагментирају у мноштва различитих и супротстављених

61 Бродел користи синтагму диференцијална географија да би описао разлике, билансе успеха и падова, које имају своје просторне димензије. Више видети: Braudel (1992), стр. 19.

62 Мартен-Фижије, А. Ритуални обичаји у грађанској приватности, у: Историја приватног живота (4) Аријес, Ф. и Диби, Ж. (2003), Београд: Clio, стр. 152-210.

63 Фабр, Д. Породице. Приватно у борби против обичаја, у: Историја приватног живота (3), Аријес, Ф. и Диби, Ж. (2002), Београд: Clio, стр. 475-508.

64 За разлику од затворених клубова и рококо салона, где је ситуација била обрнута. Више видети у: Sennett (1989), p. 109. 
интерпретативних позиција: распадало се „објективно онтолошко јединство слике света" ${ }^{5}$. Односно, више него било коме другом, литерарној јавности која критички резонује у просторима трећих места била је јасна израстајућа алармантна чињеница, „да се исти свет може различитим посма-

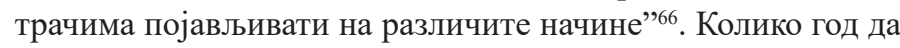
су класни положаји неједнаких утицаја и моћи били привремено суспендовани, учесницима у овом јавном критичком дискурсу било је јасно да је кафана само позорница, да је то била нова врста друштвене драматургије у којој „да би дошли до сазнања и информације, људи тог времена створили су нешто што за њих бејаше фикција - фикција да друштвене разлике не постоје" ${ }^{67}$. Док простори каснобарокних салона још увек имају умањену, псеудо-иконографију двора, мада у друштвеном смислу стоје насупрот њему, тек ће кафане „елиминисати аристократски монопол над културом”68, као и дотадашње монополе над производњом информација и знања, јер за разлику од кафана, салони су више били места „само-репрезентације и социјалног искључивања" ${ }^{\text {, }}$

Но биће то кратка генеалошка епизода која повезује трећа места и знање, рационалност и информације. Наиме, диференцијална географија супстантивно је питање спацијализације рационалности и знања. Чин великог раздвајања којем ће присуствовати револуционари након пада Бастиље неће бити појединачни случај, већ парадигма. Управо ту класицистичка рационалност засеца дубоко у простор диференцирајући и спацијализујући, раздвајајући и ограђујући до тада хомогену збрканост мноштва: ,јер, знање није створено да разуме, него да пресече" ${ }^{\text {"70 }}$. Класицистичко знање пресеца, исцртавајући до тада непостојеће границе: између лудака и криминалаца, скитница и лопова, бескућника и болесника. Њих затиче Револуција у тамницама Бастиље као збркано мноштво, неиздиференцирано и хомогено. Читава друга половина осамнаестог века, у основи, била је период одабира, стандардизација, хијерархизације и централизације знања. Тај век је такође био доба дисциплиновања знања, односно, „унутрашње организације сваког знања као

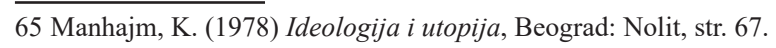

66 Исто, стр. 8.

67 Sennett, R. (1989) Nestanak javnog čovjeka, Zagreb: Naprijed, str. 106.

68 Coser, L. (1997) Man of Ideas: A Sociologist's View, New York: Free Press, p. 19.

69 Carr, G. J. (2008) Austrian Literature and the Coffee-House before 1890, Austrian Studies, 16, p. 154.

70 Fuko, M. Niče, genealogija, istorija, u: Mišel Fuko: Spisi i razgovori (ur.) Kozomara, M. (2010a), Beograd: Fedon, str. 59-88. 
дисциплине која у свом пољу истовремено има критеријуме селекције који омогућавају да се уклоне лажна знања, незнање, облике стандардизације и хомогенизације садржаја, облике хијерархизације и коначно унутрашњу организацију централизације тих знања око неке врсте аксиоматизације чињенице"71. Оне су (дисциплине знања) на тај начин груписане и организоване, увучене у неку врсту глобалног пољ $а$ или глобалне дисциплине коју зовемо наука. Ишчезавање научника-љубитеља такође је позната чињеница из осамнаестог и деветнаестог века. Са наведеним променама које „су довеле до коначног артикулисања науке и социологије као модерних дискурзивних пракси, десиле су се, по Фукоу, незаобилазне, конститутивне транзиције у дисциплинујућем поретку /.../, било је потребно дисциплину, дакле интернализовану моћ контроле и надзора, имплементирати у поље социјалног. Као последица ових нових форми дисциплиновања настају институције у којима се могло образовати позитивно знање: психијатријске клинике, болнице, школе, модерни универзитети, модерни затвори, лабораторије...”72. Захваљујући овако схваћеном дисциплиновању знања, посебно током осамнаестог и деветнаестог века, кроз (научну) праксу истраживања, конституисане су различите групе објеката, као предмета истраживања - нови објекти који испуњавају нове, дискурзивне просторе знања. Тамо где је Кант пронашао „услове могућег искуства у структури људског ума, Фуко то чини са историјским, дакле, пролазним, условима за могућност говора"

Иста матрица прогресивне спацијалне рационалности неће заобићи трећа места. У почетку помешани у трећим местима: говори о политици, о јавности, о друштву, о култури, песнички говори, научни говор, локални трачеви, заверенички шапати, бучне свађе, нејасни жамори или усамљено ћутање - доживеће диференцијације и поделе - просторне сегрегације. И као што су безумни из тамница одведени у луднице, криминалци у затворе, болесни у клинике, ле-

71 Fuko, M. (1998) Arheologija znanja, Beograd: Plato, str. 221-222.

72 Marinković, D. (2006) Konstrukcija društvene realnosti u sociologiji, Novi Sad: Prometej, str. 72.

73 Heking, J. Fukoova arheologija, u: Mišel Fuko 1926-1984-2004, (ur.) Milenković, i Marinković, D. (2005), Novi Sad: VSA, str. 129-141. Зашто je баш XVIII vek - доба класицизма - био век нових класификација, разврставања, типологија, итд? Зашто је баш крај XIX и почетак XX века раздобље „великих социјално-теоријских система - период заокупљен прогресом? Зашто су управо педесете и шездесете године време микротеорија, микроструктура, интеракција, игара и свакодневног човека? Зашто прелаз XVIII у XIX век производи френологију, а XX психоанализу и психологију личних конструката?; (Marinković, (2006), str. 69). 
прозни измештени у азиле, скитнице и бескућници смештени у workhouses, Zuchthaüser, тако ће нови простори који израстају са диференцијалном географијом одвајати сегменте кафанске хомогености у засебне просторе. Знање, рационалност и информације произведене у кафанама губиће постепено своје легитимитете. Једини легитимитет који ће постојано преостати овим трећим местима биће мњење. Поновиће се она античка матрица подвојености између $\operatorname{logosa}$ и doxe; између знања и мњењ $а$; универзалности и локалности, општости и појединачности. Заиста, када се ово узме у обзир, Хабермас је био у праву: „грађанска јавност се може најпре схватити као сфера приватних људи који окупљени чине публику”74; кафана је учествовала у процесу „самопросвећивања приватних људи на аутентичним искуствима своје нове приватности"75. Али „самосвест тог јавног резоновања"76, то самообразовано, аутономнознање јавности остаће „само”- мњење, докса. Образовање јавног мњења


кафана првобитно играла улогу „универзитета сиромашних људи" ${ }^{\text {"78 }}$, логос ће се трајно преселити у упоришне просторе западноевропског концепта рационалности: на универзитете, институте, истраживачке центре, клинике, лабораторије, краљевска друштва.

Ипак треба приметити да је и сама кафана имала своју улогу у спацијализованој рационалности. Наиме, како је могуће да Европа прихвати и тако брзо распространи један оријентални концепт доколице, друштвености и интеракција какав затичемо у кафанама, кафетеријама? „Да ли култура кафетерија (coffeehouses) служи као рано-модерни западни изум (посебно енглески), или је то била, заправо, адаптација рано-модерне исламске (посебно отоманске) културне праксе?"”79. Као и многе друге културне феномене или друштвене институције које је прихватала са Оријента - од тог њеног великог Друго ${ }^{80}$ - Запад је кафане синтетисао и интегрисао

74 Habermas, J. (2012) Javno mnjenje - istraživanje u oblasti jedne kategorije građanskog društva, Novi Sad: Mediterran Publishing, str. 81.

75 Исто, стр. 83.

76 Исто, стр. 82.

77 Coser, L. (1997) Man of Ideas: A Sociologist's View, New York: Free Press, p. 25.

78 Klein, L. E. (1996) Coffeehouse Civility, 1660-1714: An Aspect of PostCourtly Culture in England, Huntington Library Quarterly, 59(1), p. 36.

79 Zappiah, N. (2007) Coffeehouses and Culture, Huntington Library Quarterly, 70 (4), p. 672.

80 Said, E. (2008) Orijentalizam, Beograd: XX vek. 
у контекст свог идентитета, а тај идентитет се супстантивно темељио на рационалности, као што то тврди Вебер ${ }^{81}$.

Оријентални концепт кафана представљао је једну врсту супститута за традиционалну гостинску собу ${ }^{82}$ која је у домену приватне сфере представљала простор доминације мушког ауторитета: „жене нису присутне у овим собама и воде свој друштвени живот искључиво унутар породице, сродства и суседства"83. Међутим, многе карактеристике доминације аге задржане су у кафанама као јавном простору, а пре свега она доминација која искључује жене из кафанског простора. Но ипак, један аспект је био либералнији у односу на традиционални концепт гостинске собе, а то је укидање старосне и класне доминације (за мушкарце): „кафана као јавно место доступна је млађим, образованијим групама (мушкараца) који се осећају нелагодно у традиционалној хијерархији која се већином темељила на узрасту и богатству. У кафанама млади средњошколци могу да говоре; у гостинској соби мораће да се задовоље посматрањем у тишини" 84 .

Па ипак, кафана као место друштвених интеракција није примарно место изворишта социјалног капитала за жене. На неки начин, чини се да је у историји настанка и развоја кафанских простора (било да су то места за испијање кафе, чаја, пива, у комбинацији са мањим оброцима, за разлику од барова или ресторана и таверна) место за жене било опредељено другим друштвеним и културолошким факторима, који су их или потпуно искључивали из јавног простора кафане (на истоку и понегде на Балкану), или им одобравали свега неколико улога. Те улоге и места за жену и кафански простор биле су улоге газдарице/жена власника кафане (мушкарца) или самосталне, али ретко и само под одређеним условима-удовица ${ }^{85}$ : улоге оне која производи основне производне понуде једне кафане (пиће/храна), улога слушкиње (било да се ради о служењу наведених производа (конобарица), било да се ради о пружању других услуга које су потражња мушке клијентеле (сексуалне услуге или

81 Veber, M. (2011) Protestantska etika i duh kapitalizma, Novi Sad: Mediterran Publishing.

82 Beeley, B.W. (1970) The Turkish Village Coffeehouse as a Social Institution, Geographical Review, 60(4), p. 481.

83 Исто, стр. 479.

84 Исто, стр. 481.

85 Capp, B. Gender and the Culture of the English Alehouse in Late Stuart England, in: The Trouble with Ribs: Women, Men and Gender in Early Modern Europe, eds. Korhonen, A. and Lowe, K. (2007) Helsinki: Helsinki Collegium for Advanced Studies, p. 103-27. 
услуге сличних ужитака). Но, како пише Мартин, присуство жене у кафани не имплицира сексуални неморал, већ има и бројне друге легитимне разлоге ${ }^{86}$. Као што се да приметити, све ове улоге служе заправо предузетничким активностима развијања кафане као места зараде, а не улоге конзумената кафане као места социјалних интеракција, места провођења слободног времена, места одмора, забаве и релаксације од свакодневице радног места, породице и сл. Простор кафане за жене је такође био и простор друштвене контроле исправности жене у њеним другим друштвено одобреним улогама (мајке, супруге, домаћице). Правила дозвољеног понашања жене у јавном простору (кафане) подразумевало је поштовање кодекса облачења, али и путање погледа ${ }^{87}$, који је морао да одаје захтевану чедност, за разлику од јасно уочљивих боја, одевних предмета, погледа, гласноће говора, и других сигнала у понашању жена у друштвено прихваћеним улогама, у јавном простору, у простору кафане посебно. Примарно правило за удату жену било је да при уласку у кафану мора да има за пратиоца или законитог супруга или другог одобреног мушког пратиоца ${ }^{88}$. У урбаним срединама попут Лондона, за жену је било дозвољено да посети оваква места и самостално, али само током дана, „уколико се понаша пристојно, тиха је и не задржава се предуго" ${ }^{89}$. Дакле, не може се рећи да је кафански простор био затворен за жене, али је био ограничен јасним правилима понашања, која су ипак жену држале подаље од овог простора. На крају крајева, женино место је у традиционалном смислу увек блиско везано за дом и децу, а деци тек место није у кафани.

Но, које жене су саставни део кафане западног друштва? Без каквих жена су кафане можда и мање атрактивна места за њихове уобичајене посетиоце? Стереотипи виђени у уметности $^{90}$, незаобилазне су женске фигуре које су саставни део кафанских простора и свакодневице кафане. Међутим, сагледавајући промене улоге жена током историје, оне су

86 Lynn, A. M. (2001) Alcohol, Sex, and Gender in Late Medieval and Early Modern Europe, Basingstoke: Palgrave; Kümin, B. and Tlusty, A. B. (2002) The World of the Tavern. The Public House in Early Modern Europe, Aldershot: Ashgate.

87 Hanawalt, B. A. (1998) Medieval English Women in Rural and Urban Domestic Space, Dunbarton Oaks Papers, 52, p. 24.

88 Capp, B. Gender and the Culture of the English Alehouse in Late Stuart England, in: The Trouble with Ribs: Women, Men and Gender in Early Modern Europe, eds. Korhonen, A. and Lowe, K. (2007), Helsinki: Helsinki Collegium for Advanced Studies, p. 103-27.

89 Исто, стр. 120.

90 Ликовна уметност - импресионистичке представе Бара у ФолиБержеру, телевизија - Едит из серије Ало, ало. 
се видљиво одразиле и на „женску конзумацију” кафана. ${ }^{91}$ Дакле, облик дозвољености гласи „можете бити гошће, али ипак само на ограничено време”. Шта је са традиционално дозвољеним улогама за жену у кафани? Газдарица, конобарица, забављачица. Ове улоге и даље остају незаобилазне у перцепцији кафане као трећег места формирања социјалног капитала у контексту ширег друштвеног и културолошког оквира живота заједнице и интеракције полова и полних улога.

Осим што је прихватила укидање оваквих доминација, а задржала границе према женама, окцидентални концепт кафане је понудио и радикално другачији однос према говоpy. Кафане су, наиме, следиле исту ону матрицу као и друге институције упрегнуте у процес рационализације: „Монополизму и тајном знању оријенталне тираније, Европа супротставља универзално саопштавање сазнања, бесконачну и слободну размену говора"92. Окцидентална трећа места равноправно су учестововала, барем у почетку, са другим снагама рационализације, у процесима демонополизације, деритуализације и размађијавања тајних знања, не дозвољавајући скривања у јавном простору. Кафана је била место размађијавања старих представа, далеко од цркве, породице и старих ауторитета. Она гради своју алтернативну културу од контакта, од сусрета, интеракција, од говора привремено „деструктурираних” људи. Но ипак, не у свакој прилици. Енглеске и француске кафане осамнаестог века била су и прва упоришта масонских ложа као тајних друштава која су носиоци „тајних” знања. Многе ложе и данас носе имена кафана, а традиција окупљања слободних зидара у кафанама још је део постритуалног окупљања. Јер грађанско друштво „није празнина коју је пожелео сумњичави законодавац, него мравињак с алвеолама дружења у којој врви од тајни"93.

Но вратимо се за тренутак једном примеру микро-географије у периоду када још доминира збрка неиздиференциране хетерогености. Фарж на следећи начин описује архитектуру

91 До пре само четрдесетак година, тешко је у неким срединама било замислити да жена самостално буде посетилац кафанског простора (простор јужне Србије, Црне Горе). Данас, је та слика умногоме измењена, у урбаним срединама посебно. Жене се у кафанама равноправно окупљају, забављају, проводе слободно време. Да ли су и колико стигматизоване, зависи од урбанизованости простора за живот. Но и даље жене у кафанама не склапају послове, и проводе много мање времена у односу на мушкарце.

92 Fuko, M. Poredak govora, u: Mišel Fuko 1926-1984-2004, (prir.) Milenković, P. i Marinković, D. (2005a), Novi Sad: VSA, str. 37-58.

93 Перо, М. Начини становања, у: Историја приватног живота (4), Аријес, Ф. и Диби, Ж. (2003), Београд: Clio, стр. 245-260. 
урбане свекодневице: „[О]д полуспрата до дашчане таванске преграде све је пренасељено, а газде покушавају да извуку корист из сваке мрвице простора" 94 . То је призор још класно неиздиференциране просторне структуре једне просечне зграде 18. века; иако је простор исцепкан ${ }^{95}$, зграде насељавају они који су још увек класно блиски; још нема оног режима разврставања - капиталистичког урбанизма - који ће век касније расподелити простор по класама; просторно сегрегирати и одвојити, прво раднике од капиталиста, а потом ће се матрица сегрегације применити много дубље и суптилније, одвајајући мајсторе и квалификоване раднике од калфи и шегрта, тек приучене и још неквалификоване радне снаге; из те помешане збрке издвојиће се чиновници, трговци, адвокати, лекари, све оно што ће чинити будућу средњу класу. „Стамбена зграда је пре свега јавна сцена на којој се једни потврђују а други бивају прогоњени, а ништа се не може доживети тајно или кришом. Брачне свађе, тајне љубави, бучни станови, немирна деца, све се чује и сазна без по муке"96. Но, „на послу живот није ништа заштићенији"97 од погледа и звукова који као флуиди теку улицама где су смештене, заједно са претходно описаним становима, радионице и продавнице. Оне су смештене између породичног живота незаштићеног и измешаног са туђим гласовима, са странцима у пролазу који су ту само једну ноћ. Простори рада су „посредни простори између споља и унутра"98.

У просторној расподели рационалности која је захватила европу класицистичког раздобља, кафанама је све више измицала улога рационалности и трезвености. На известан начин, она је све више личила на хетеротопију - један плутајући простор никада до краја усидрен у јавно, никада до краја усидрен у приватно; никада до краја истински простор рационалности и трезвености. Ако је у почетку и била простор логоса, онда је то био грађански логос образован говором слободних људи, све више аутономних субјеката, приватних појединаца који јавно резонују без обзира на друштвени положај. Тај грађански логос био је и рефлексиван по својој природи, али то је био логос ограничене рефлексивности, коју мњење дели са идеологијом ${ }^{99}$. Обележја новог дискурса

94 Фарж, А. Породице. Част и тајна, у: Историја приватног живота (3), Аријес, Ф. и Диби, Ж. (2002), Београд: Clio, стр. 509-540.

95 Исто, стр. 512.

96 Исто.

97 Исто.

98 Исто.

99 Gouldner, A.W. (1976) The Dialectic of Ideology and Technology, London: The Macmillan Press. 
који се, према Хабермасовом мишљењу, такође јавља упоредо са развојем либералне грађанске јавности су следећа: прво, то су нове врсте дискусија које се јављају у кафанама, салонима и на другим јавним местима и оне траже једну нову врсту друштвеног опхођења и говора који више не претпоставља једнакост статуса, већ се од њега потпуно апстрахује: „церемонијалу чинова и положаја супротставља се такт равноправности"; затим, није реч о томе да се са кафанама остварила идеја јавности, али се она захваљујући њима институционализује као идеја, као објективни захтев који се материјализује; даље, дискусија која се јавља међу новом публиком претпоставља отварање проблема у подручјима која пре тога нису довођена у питање - теме којима јавност почиње критички да се бави биле су монопол интерпретације црквених и државних ауторитета (од предикаонице до филозофије, књижевности и уметности); такође, исти ток којим се култура преводи у облик робе и тако постаје култура о којој се може дискутовати води ка „научној отворености” публике - дискутабилна питања постају „општа не само у смислу своје значајности, већ и у погледу своје приступачности" $"$.

Анализирајући записе и његове примене, Шартије ће приметити да паралелно са генеалогијом грађанске јавности можемо пратити и генеалогију нових видова „односа са другима и нову врсту власти"101. При томе, не само да се власт и државни апарат све више ослањају на текст, „на записано, при изрицању правде и уређивању друштва"102, већ је умеће читања и записивања постао „обавезан услов за појаву нових навика из којих се састоји приватност појединаца"103. Пре појаве либералног модела грађанске јавности у којој почиње да се комуницира безименим гласовима ${ }^{104}$, јавни говор био је искључива повластица друштвених ауторитета - носилаца власти. Нови режим дискурса није био могућ у друштвима старог режима ${ }^{105}$. Али књига и књижница више су припадале просторима интиме и приватности. Књижница

100 Habermas, J. (2012) Javno mnjenje - istraživanje u oblasti jedne kategorije građanskog društva, Novi Sad: Mediterran Publishing, str. 91-92.

101 Шартије, Р. Запис и његове примене, у: Историја приватног живота (3), Аријес, Ф. и Диби Ж. (2002), Београд: Clio, стр. 100-142.

102 Исто, стр. 107.

103 Исто, стр. 106.

104 Fuko, M. Poredak govora, u: Mišel Fuko 1926-1984-2004, (prir.) Milenković, P. i Marinković, D. (2005a), Novi Sad: VSA, str. 37-58.

105 Koselleck, R. (1988) Critique and Crisis: Enlightenment and the pathogenesis of modern society, Cambridge, MA: The MIT Press; Saunders, D. (1997) Anti-lawyers: Religion and the critics of law and state, London: Routledge. 
je, као и музеј, била такође хетеротопија ${ }^{106}$ у коју се склања од јавности. Зато Аријес и примећује нечувену појаву између 16. и 18. века: „читање одвојено од заједнице, у приватности која допушта размишљање насамо" 107 ; библиотека је повлачење од света ${ }^{108}$. У микро-географији диференцијације простора класицистичког раздобља не само да се појављују простори јавности са салонима, кафанама, позориштима, већ паралелно израстају простори интиме и осаме: баште, кабинети, библиотеке, вртови као суптитути пасторалне усамљености - једна археологија интимног ${ }^{109}$. Ако је на почетку ширења читаности, књига била питање интиме, онда је јасно зашто је кафана била место покретања сопствених медија: дневних новина, памфлета, магазина, петиција. Подсетимо да су Татлер (1709-11), Спектатор (1711-14) и Гардијан (1713) - као парадигме јавне информисаности настали у енглеским кафанама ${ }^{110}$. Тако се оснивач Татлера, на почетку увек обраћа цееьеним грађанима који више живе у кафанама него у својим радњама, јер „мушко време јесте време посвећено јавном животу ${ }^{111}$. Прве јавне дебате између мушкараца и жена остварују се преко памфлета и петициja. На Женску петииију против кафе (The Women's Petition Against Coffee) ${ }^{112}$ (а заправо кафана̂) из 1674, мушкарци узвраћају Мушким одговором на женску петищију (The Men's Answer to the Womens Petition against Coffee) ${ }^{113}$. Исто тако,

106 Fuko, M. Druga mesta, u: Mišel Fuko 1926-1984-2004, (prir.) Milenković, P. i Marinković, D. (2005b), Novi Sad: VSA, str. 29-36.

107 Шартије, Р. Запис и његове примене, у: Историја приватног живота (3), Аријес, Ф. и Диби, Ж. (2002), Београд: Clio, стр. 100-142.

108 Исто, стр. 123.

109 Renam, O. Utočišta intimnosti, u: Istorija privatnog života (3), Arijes, F. i Dibi, Ž. (2002), Beograd: Clio, str. 189-236.

110 Cowan, B. (2004) Mr. Spectator and the Coffeehouse Public Sphere, Eigh teenth-Century Studies, 37(3), p. 345-366.

111 Мартен-Фижије, А. Ритуални обичаји у грађанској приватности, у: Историја приватног живота (4), Аријес, Ф. и Диби, Ж. (2003), Београд: Clio, стр. 152-210.

112 The Humble Petitions and Address of Several Thousands of Buxome GoodWomen, Languishing in Extremity of Want, and contained the phrase -The Age of Man, Now Cramp't into an Inch, that was a Span. (Смерни протест и молба коју упућује неколико хиљада благоугодних жена, које вену од крајње потребитости, а што се најпре може изразити фразом-мушки род што се на палаи стесаше, а некад к'о педаљ беше).

113 Could it be Imagined, that ungrateful Women, after so much laborious Drudgery, both by Day and Night, and the best of our Blood and Spirits spent in your Service, you should thus publickly Complain? Certain we are, that there never was Age or Nation more Indulgent to your Sex; have we not condiscended to all the Methods of Debauchery...? (Зар се уопите да замислити да ће незахвалне жене, после толиких дана и ноћи напорног изгарања и трошења и сриа и душе на услузи ғима, пожелети да се овако јавно пожале? Сигурни смо да никад не беше другог народа који би према 
као што се приватни, интимни запис артикулише кроз дневнике, исповести и писма (као они Семјуела Пеписа), јавни се запис артикулише као догађај доступан у локалном листу и намењен је свима: „Као специфично дискурзивна институција, кафана треба да се посматра у контексту историје дискурса и комуникативних пракси у друштву"114. Дакле, ако је књижница била склониште од света, онда је кафана била једна нова врста дискурзивне јавности. У њеном средишту није књига, која је тада још увек доминантно религијско штиво - а кафана је познато место „,атеистичког мишљења"115 - већ локални магазин, информација, трач, сплетка, политички догађај, вест издалека која још дуго неће бити садржај књиге: What are news from Tripoli? ${ }^{116}$, пита се у кафани. То је права комуникативна револуција, а не ритуално читање стално истих текстова, пре свега Библиje. Али ево једне препоруке ерла од Њукастла Чарлсу II из 1660. године која ће наслутити губитак крхког легитимитета кафанске рационалности: „Не би требало да буде расправа (disputations) осим на универзитетима; не би требало да буде књига о религији или политичким контроверзама осим на латинском; са друге стране, све побожне књиге треба да су на енглеском; не би требало да буде написаних књига изузев оних које напишу академски сертификовани 'филозофи'; на сваку књигу која може да донесе чак и најмањи профит цркви или држави, треба бацити клетву и спалити је, а аутора треба жестоко казнити, чак и на смрт"117.

Овим се улази у дубљу анализу не само простора једне дискурзивне праксе, већ и у питање борбе око истине, као и у питање јавно и дискурзивно конструисане саморефлексије представе о себи у свакодневици јавног. Јер оно што може да се ишчита у запису јавног, то је само огледало догађаја у којем учествују исти они који читају: то је својеврсна рефлексивна петља где се аутономни субјект јавног догађаја враћа сам себи посредством онога што је записано као јавно. Сада обични и разноврсни људи почињу да производе „истину” о сопственом свету, о свету који је створен њиховим праксама

вашем роду био попустљивији; та зар не пристајасмо на сваку врсту разузданости ...?)

114 Klein, L. E. (1996) Coffeehouse Civility, 1660-1714: An Aspect of Post-Courtly Culture in England, Huntington Library Quarterly, 59(1), p. 32.

115 Cowan, B. (2001) What Was Masculine about the Public Sphere? Gender and the Coffeehouse Milieu in Post-Restoration England, History Workshop Journal, 51, p. 140.

116 Pincus, S. (1995) Coffee Politicians Does Create: Coffeehouses and Restoration Political Culture, The Journal of Modern History, 67 (4), p. 819.

117 Klein, L. E. (1996) Coffeehouse Civility, 1660-1714: An Aspect of PostCourtly Culture in England, Huntington Library Quarterly, 59(1), p. 30-51. 
и њиховим говором. Тек ту се открива једна велика „истина": свет који може да се промени је људски свет, састављен од пракси, дискурса и идеја који су производи истих тих људи. Можда по први пут, то је свет који може да се промени говором. Јер од говора је и створен. Када Фуко узвикне: „истина је од овог света; у њему је произведена"118, управо то може да се примени на тај грађански логос произведен у друштвености кафана. То видимо на примеру језика, јер он више није ни инструмент ни производ, већ непрестана активност. Он се више не везује за ствари, већ за људе: „Језик је људски: своје поријекло и свој раст дугује нашој пуној слободи; он је наша историја и наше насљеђе"119. Зато људи могу да почну да говоре о ономе што раде. То је највећи социјални капитал рађајућег грађанског друштва и његових трећих места.

Кафана није место говора о трансцендентном, већ о иманентном - о овом свету. Тако је и кафана увучена у ту велику класицистичку игру произвођења истине. Ако дискурс о природи свој легитимитет задобија у просторима колеџа и научним друштвима, краљевским друштвима, онда је рани дискурс о друштву задобио свој легитимитет на улици, у кафани, у салону. Енфантен и Базар, као и Сен-Симон и Конт, као и Кондорсе и Дидро, имају још увек у себи нешто луталачко, то је „истина” о нашем заједничком свету која се мора објавити на улици, у кафани, међу људима који су и субјекти и објекти те „истине”. Уосталом и чланови Royal Society, велики природњаци Роберт Бојл, Роберт Хух или Хенри Олденбург о својим су великим идејама дискутовали у кафани Геравејс (Garraway's), пре него што су их саопштили и легитимисали у просторима Краљевског друштва ${ }^{120}$. Производња „истине” о сопственом свету није ни најмање безазлена. Тај говор плаши, породицу колико и цркву, исто колико и власт: „Но, шта је толико опасно у чињеници да људи говоре, и да се њихов говор бескрајно множи? Где је, дакле, опасност?"'121. Пре свега, дискурси о једној новој врсти света, не више божанског и не више краљевског, већ заједничког света који се може мењати: то је опасно и за краља и за цркву. Али то је опасно и за нове дисциплинарне

118 Fuko, M. Razgovor sa Mišelom Fukoom, u: Moć/znanje: odabrani spisi $i$ razgovori 1972-1977, Fuko, M. (2012b), Novi Sad: Mediterran Publishing, стр. 113-134.

119 Fuko, M. (1971) Riječi i stvari, Beograd: Nolit, str. 335.

120 Pincus, S. (1995) Coffee Politicians Does Create: Coffeehouses and Restoration Political Culture, The Journal of Modern History, 67 (4), p. 820.

121 Fuko, M. Poredak govora, u: Mišel Fuko 1926-1984-2004, (prir.) Milenković, P. i Marinković, D. (2005a), Novi Sad: VSA, str. 37-58. 
обрасце чију генеалогију можемо да пратимо упоредо са генеалогијом јавности, приватности и кафана. Породица је већ увучена у нове технологије надзора и дисциплинарних технологија. Она постаје надзирућа машина забринута за дечију сексуалност, за моралност и за репродукцију. Већ јој је у општој ерозији и расутости надлежности и ауторитета поверено оно што је некада радила црква. Исповедаоница је сада дечији или брачни кревет. Производња је такође већ надзорна машина: продуктивност рада зависи од покрета који су надзирани. Рана фабрика и мануфактура своју продуктивност дугују подједнако технологији погледа колико и техничким иновацијама. Наравно, и јавност се стално надгледа. Све више постаје сумњива за власт. Са настанком полиције контролисаће се јавни живот, њен успостављени ред и мир ${ }^{122}$. Кафане су политичка опасност: оне „у позадини примају у заклон тајне састанке или синдикалне коморе"123. Паноптикон се расуо по друштвеном простору - јавном и приватном.

Међутим, кафана као и свака хетеротопија, остаје изван доминантних дисциплинарних образаца. Изван контроле породице и изван контроле производње, изван контроле суверене власти - у њима још није инсталиран паноптички објектив. Кафане се плаше управо они који чувају дисциплинарни и надзирући поредак: кафане се боје жене: оне су задужене за репродукцију и дисциплински режим породичног живота. Кафане се плаше капиталисти: они који су задужени за режим продуктивности. Кафане се плаши власт и суверен (јер тамо се кују завере): онај који је задужен за правни поредак, за режим формалних дисциплинских пракси. Коначно, кафане се плаши и црква, јер то је питање монопола над моралом; кафана је постала место у којем се саопштава оно што се некада саопштавало у тишини исповедаонице, али сада без моралних или неких других санкција. Говор почиње да кружи, да циркулише, да тече у кафани, неоптерећен принудама формалности, неоптерећен истином или логиком изговореног, неоптерећен претећим казнама. Ето шта је опасно у чињеници да људи говоре: „Опасно је кад реч провали, њоме се укида сигурност именованог"124. Речи почињу да теку као набујале реке: „Необузданост језика толико је уобичајена међу Парижанима, да сваки кафански сто има

122 Fuko, M. (2014a) Bezbednost, teritorija, stanovništvo, Novi Sad: Mediterran Publishing.

123 Перо, М. Начини становања. у: Историја приватног живота (4), Аријес, Ф. и Диби, Ж. (2003), Београд: Clio, str. 245-260.

124 Фарж, А. Породице. Част и тајна, у: Историја приватног живота (3), Аријес, Ф. и Диби, Ж. (2002), Београд: Clio, str. 509-540. 
свог говорника... сазнати, чути од другога, рећи другоме, то је најбољи начин да се измери сопствено место, да се оно опет и опет размотри доводећи другога у однос према себи" 125 - то је амбијент кафанског простора; те географије у којој тече говор; те хидрографије многих говорних токова, од поетских до политичких; од простачких до полутајних; од оговарања до завереничких шапутања. „Ако реч царује, велика је опасност да једног дана постанемо њена жртва"126. Солидарност упостављена на трећим местима, управо преко говора, истим тим говором и речима може бити срушена: „[Р]азбијају се односи једнакости и изграђује се нова, још видљивија хијерархија: неко је изненада стављен на одстојање"127. Но тај прекид солидарности, примећује Фарж, више је налик модификацији; он је пре једна модулащија ${ }^{128}$ друштвености и њене просторно ситуиране солидарности.

Проблем генезе трећих места као хетеротопија грађанског друштва и као једног новог начина спацијализације дискурса, треба посматрати и у оквиру процеса одвајања говора од представе. То је несумњиво један од битних момената трансформације јавности, али и шире трансформације која се у западној култури одиграла крајем XVIII века и она се може означити као „повлачење знања и мисли изван домена представе"129. Док је стари, ритуални режим дискурca значио да се експресивна вредност говора исцрпљује у репрезентоваьу ствари, објеката и односа̂, јавни говор као ритуализовани говор, одређивао је истовремено квалификације говорника, говора и изговореног. Ауторизација говора је подразумевала јасну друштвену позицију говорника, а у његове исказе су били учитани његов положај у друштвеној структури, позиција моћи или друштвено-политичка улога. Једна нова „снага модерног искуства” конституише се захваљујући краху владавине репрезентативног говора и „династије представе која саму себе означава и у свом прождирању у домену речи исказује успавани поредак ствари"130.

125 Исто, стр. 518.

126 Исто.

127 Исто, стр. 519.

128 Delez, Ž. (1989) Fuko, Novi Sad: Izdavačka knjižarnica Zorana Stojanovića.

129 Fuko, M. (1971) Riječi i stvari, Beograd: Nolit. У питању је елемент ширих процеса друштвене и историјске деритуализације и детрадиционализачије које је Макс Вебер идентификовао као процес рационализације западног друштва - Entzauberung der Welt (Veber 2011).

130 Исто, стр. 260. Класицистички поредак је „оперисао у сталном простору са идентичностима и разликама које су раздвајале и спајале ствари: такав поредак суверено је владао, али увек у нешто друкчијем облику и под различитим законима, над људским говором, сликом природних бића и размјеном богатства" (Fuko (1971), str. 266-267). 
Заправо, у дугом процесу деритуализачије говора и одвајања језика од представе, сам говор морао је да задобије и нови облик легитимитета, истинитости, важења које ће омогућити и развој научног мишљења, права и државне администрације. На том путу, говор је прошао спацијализацију кроз различите институте јавности и у првом реду кроз трећа места. Захваљујући трансформацији представе у дискурс, отворена је могућност за разумевање једне нове комбинаторике дискурса и пракси, односно једне нове економике њихових веза у јавном домену друштва. ${ }^{131}$

\section{Закључак}

Кафана је морала да се бори за простор. Да се смести између породице и производње, између продуктивне сексуалности и продуктивности рада. Између два простора који се труде да подигну зидове око појединца. Ту је њена улога била ослободилачка. Али, да ли је избегла односе моћи? Свакако није. Она је учествовала у ерозији суверених облика власти и у образовању једног новог типа моћи: „Овај нови тип моћи, који се више не може дефинисати речником суверености, је, верујем, један од великих изума буржоаског друштва; био је једно од фундаменталних оруђа успостављања индустријског капитализма и типа друштва који је с њим сагласан. Та несуверена моћ, страна, дакле, форми суверености, јесте дисциплинарна моћ, која се не може описати и оправдати речником теорије суверености, и која би природно морала довести до самог нестанка те велике правне грађевине теорије суверености"132. Генеалогија кафана као генеалогија борбе за простор је питање слободе усред израстања надзирућег друштва контроле. Кафана је прекид, хетеротопија у друштвеној географији која је, од доба класицизма, под присмотром снага израстајућег капитализма.

131 То је, хабермасовски речено, нова економика дискурса модерне, која ће омогућити да различити облици ициьно-рационалног делања (науке, уметности, морала) постану аутономне, специјализоване и регионализоване делатности - кроз развој друштвених институција. О томе пише Хабермас у тексту под називом Модерна - недовршен пројекат: „Док се слике свијета распадају, те се наслијеђени проблеми могу обрађивати одвојено, са специфичних стајалишта истине, нормативне исправности, аутентичности или љепоте, као питања спознаје, као питања правде, као питања укуса, у нововјековљу се диференцирају вриједносне сфере знаности, морала и умјетности. У одговарајућим културним суставима дјеловања институционализирају се знанствени дискурси, моралнотеоријска и правнотеоријска истраживања, умјетничка производња и умјетничка критика као посао стручњака" (Habermas (2009), str. 102).

132 Fuko, M. Predavanje od 14. januara 1976, u: Moć/znanje: odabrani spisi $i$ razgovori 1972-1977, Fuko, M. (2012c), Novi Sad: Mediterran Publishing, str. 97-112. 
Треба укратко напоменути да је постојао још један „пут за легитимацију кафана" 133 који није водио ка критичкој дискурзивности и мњењу, већ ка цивилизованости. Упркос бројним морализаторским придикама које се вековима упућују кафанама, управо је рана европска кафана од друге половине седамнаестог века била место нове врсте друштвене углађености и цивилизованости. Стога је оправдана критика упућена Норберту Елијасу, јер у његовом Процесу цивилизације ${ }^{134}$ - као процесу углађивања понашања и цивилизовања - централно има двор. Чуди да је Елијасу кафана измакла из поља анализе процеса цивилизовања, јер кафана је била „алат за конструкцију пристојне публике”"135. Неоспорна је вредност и оригиналност Елијасовог дела, али оно захвата цивилизованост у суженој перспективи која има путању од горе према доле, од аристократије и двора према будућем углађеном грађанству и пристојној урбаној свакодневици. Но, цивилизованост није толико монолитна категорија да може да се сведе једино на „демократизацију” дворске и аристократске културе. Њени су извори многоструки. У сенци доминантне дворске цивилизованости, на измаку средњег века, културни садржаји већ имају свој аутономни живот створен изван образаца дворске културе. Иако још увек постоји естетика имитације двора, пре свега у салонима и позориштима, она је више успутни декор. Главни јунак који израста у просторима кафана је говор који слободно тече; говор који подразумева „чисту” друштвеност, а она се гради и одржава учтивошћу: „учтивост је централна не само у мапирању културне идеологије у осамнаестом веку, већ такође и за разумевање карактеристичних форми културних организација и пракси"136. Углађена друштвеност, свакако, није само питање града, иако се стално истиче да је кафана била „есенцијална институција урбаног живота [Енглеске]”137. Када часни Ајзак Волтон пише свог Савршеног риболовия 1653. године ${ }^{138}$, дело које енглеска публика ставља на треће место по читаности, одмах након Библије и Шекспирових дела, он је окружен пасторалним пределом Авона и Винчестера, бистрим потоцима а не градским улицама, традиционалним енглеским пивницама (ale-house), а не местима где

133 Klein, L. E. (1996) Coffeehouse Civility, 1660-1714: An Aspect of Post-Courtly Culture in England, Huntington Library Quarterly, 59(1), p. 34.

134 Elijas, N. (2001) Proces civilizacije, Novi Sad: Izdavačka knjižarnica Zorana Stojanovića.

135 Klein, L. E. (1996) Coffeehouse Civility, 1660-1714: An Aspect of Post-Courtly Culture in England, Huntington Library Quarterly, 59(1), p. 32.

136 Исто, стр. 51.

137 Исто, стр. 31.

138 Volton, A. (2016) Savršeni ribolovac, Novi Sad: Mediterran Publishing. 
се пије само кафа. Своје јутарње точено пиво Волтон испија у Cock ale-house ${ }^{139}$ спремајући се да кроз лик Пискатора поучи Вијатора не само риболову, већ пристојном понашању, слушању и учењу, једном новом врстом углађене дискурзивности. Те 1653. године када настаје прво издање Савршеног риболовца, протекло је тек три године од оснивања прве кафеџинице (coffeehouse) у Оксфорду (1650) и само годину дана од прве лондонске (1652), али процес цивилизаиије и углађивања већ је живео на просторима удаљеним од двора и града.

Кафане „заслужују наше историјско памћење”140 не само због тога што постоји њихово историјско трајање, већ због тога што је историја кафана упоредна историја мноштва великих друштвених, политичких, културних и економских питања. Преко генеалошких анализа о њиховом настанку, трајању и променама, може да се отвори питање генезе европске грађанске јавности, грађанског друштва и модерне, као што је то урадио Хабермас; питање комуникационе револуције, идеологије и културе критичког дискурса, као што је то урадио Гулднер; или питање друштвеног капитала и индивидуалних слобода, као што је то урадио Олденбург. Коначно, ако су се преко кафана као „малих” места отварала велика питања, зашто се управо преко њих не би могло отворити једно од кључних генеалошких питања - за нас Европљане - ко смо ми? Ко смо ми у нашем времену? То је оно кључно генеалошко питање које је пре нас поставио Кант (1783) а обновио Фуко проблематизујући велике историјске наративе (histoire totalisante) и враћајући се ничеанској генеалогији.

\section{ЛИТЕРАТУРА:}

Аријес, Ф. и Диби, Ж. (2002) Историја приватног живота (3), Београд: Clio.

Аријес, Ф. и Диби, Ж. (2003) Историја приватног живота (4), Београд: Clio.

Beeley, B.W. (1970) The Turkish Village Coffeehouse as a Social Institution, Geographical Review, 60(4), p. 475-493.

Braudel, F. (1992) Struktura svakidašnjice: materijalna civilizacija, ekonomija i kapitalizam od 15. do 18. stoljeća, Zagreb: August Cesarec.

Brodel, F. (2001) Mediteran i mediteranski svet u doba Filipa II (I), Beograd/ Podgorica: Geopoetika.

139 J. Y. A. (1846/1847) Examples Of London Coffee-House And Tavern Tokens, The Numismatic Chronicle and Journal of the Numismatic Society 9, p. 64.

140 Johnson, S. (2009) A Meeting of Minds, RSA Journal, 155(5538), p. 19. 
Capp, B. Gender and the Culture of the English Alehouse in Late Stuart England, in: The Trouble with Ribs: Women, Men and Gender in Early Modern Europe, (eds.) Korhonen, A. and Lowe, K. (2007), Helsinki: Helsinki Collegium for Advanced Studies, p. 103-27.

Carr, G. J. (2008) Austrian Literature and the Coffee-House before 1890, Austrian Studies, 16, p. 154-171.

Coser, L. (1997) Man of Ideas: A Sociologist's View, New York: Free Press.

Cowan, B. (2001) What Was Masculine about the Public Sphere? Gender and the Coffeehouse Milieu in Post-Restoration England, History Workshop Journal, 51, p. 127-157.

Cowan, B. (2004) Mr. Spectator and the Coffeehouse Public Sphere, Eighteenth-Century Studies, 37(3), p. 345-366.

Cowan, B. (2005) The Social Life of Coffee: The Emergence of the British Coffeehouse, New Haven \& London: Yale University Press.

Cresswell, T. (1996) In Place/Out of Place: Geography, Ideology, and Transgression, Minneapolis: University of Minnesota Press.

Delanty, G. (1995) Inventing Europe: Idea, Identity, Reality, London: Macmillan Press.

Delez, Ž. (1989) Fuko, Novi Sad: Izdavačka knjižarnica Zorana Stojanovića.

Delimo, Ž. (1987) Strah na Zapadu, Novi Sad: Izdavačka knjižarnica Zorana Stojanovića.

Ђорђевић, Д. Б. (2011) Казуј крчмо Церимо: периферијска кафана и около юе, Београд: Службени гласник.

Ђорђевић, Д. Б. (прир.) (2012) Кафанологија, Београд: Службени гласник.

Elijas, N. (2001) Proces civilizacije, Novi Sad: Izdavačka knjižarnica Zorana Stojanovića.

Фабр, Д. Породице. Приватно у борби против обичаја, у:

Историја приватног живота (3), Аријес, Ф. и Диби, Ж. (2002), Београд: Clio, стр. 475-508.

Фарж, А. (2002) Породице. Част и тајна, у: Историја приватног живота (3), Аријес, Ф. и Диби, Ж. (2002), Београд: Clio, стр. 509-540.

Фоазил, М. (2002) Записи из приватности, у: Историја приватног живота (3), Аријес, Ф. и Диби, Ж. (2002), Београд: Clio, стр. 288-322.

Foucault, M. Du gouvemement des vivants, in: Dits et écrits (19801988, IV), (eds.) Defert, D. and Ewald, F. (1994a), Paris: Gallimard, p. 125-129.

Foucault, M. (1994b) Théories et institutions pénales, in: Dits et écrits (1980-1988, IV), (eds.) Defert, D. and Ewald, F. (1994a), Paris:

Gallimard, p. 389-393.

Fuko, M. (1971) Riječi i stvari, Beograd: Nolit.

Fuko, M. (1990) Predavanja, Novi Sad: Svetovi. 
Фуко, М. (1997) Надзирати и кажъавати: настанак затвора, Нови Сад: Издавачка књижарница Зорана Стојановића.

Fuko, M. (1998) Arheologija znanja, Beograd: Plato.

Fuko, M. Poredak govora, u: Mišel Fuko 1926-1984-2004, (prir.) Milenković, P. i Marinković, D. (2005a), Novi Sad: VSA, p. 37-58.

Fuko, M. Druga mesta, u: Mišel Fuko 1926-1984-2004, (prir.) Milenković, P. i Marinković, D. (2005a), Novi Sad: VSA, p. 29-36.

Fuko, M. (2006) Volja za znanjem: istorija seksualnosti I, Loznica: Karpos.

Fuko, M. Niče, genealogija, istorija, u: Mišel Fuko: Spisi i razgovori, (ur.) Kozomara, M. (2010a), Beograd: Fedon, str. 59-88.

Fuko, M. Dva ogleda o subjektu i moći, u: Mišel Fuko: Spisi i razgovori, (ur.) Kozomara, M. (2010a), Beograd: Fedon, str. 384-411.

Fuko, M. Pitanja Mišelu Fukou o geografiji, u: Moć/znanje: odabrani spisi i razgovori 1972-1977, Fuko, M. (2012a), Novi Sad: Mediterran Publishing, str. 69-82.

Fuko, M. Razgovor sa Mišelom Fukoom, u: Moć/znanje: odabrani spisi i razgovori 1972-1977, Fuko, M. (2012a), Novi Sad: Mediterran Publishing, str. 113-134.

Fuko, M. (2012c) Predavanje od 14. januara 1976, u: Moć/znanje: odabrani spisi i razgovori 1972-1977, Fuko, M. (2012a), Novi Sad: Mediterran Publishing, str. 97-112.

Fuko, M. (2014a) Bezbednost, teritorija, stanovništvo, Novi Sad: Mediterran Publishing.

Fuko, M. (2014b) Tehnologije sopstva, Loznica: Karpos.

Gofman, E. (2000) Kako se predstavljamo u svakodnevnom životu, Beograd: Geopoetika.

Gofman, E. (2011) Azili, Novi Sad: Mediterran Publishing.

Gouldner, A.W. (1976) The Dialectic of Ideology and Technology, London: The Macmillan Press.

Habermas, J. (2012) Javno mnjenje - istraživanje u oblasti jedne kategorije građanskog društva, Novi Sad: Mediterran Publishing.

Habermas, J. (2009) Moderna - nedovršen projekat, Politička misao, 46/2, str. 96-111.

Haine, S.W. (1992) Café Friend: Friendship and Fraternity in Parisian Working-Class Cafes, 1850-1914, Journal of Contemporary History, 27(4), p. 607-626.

Hanawalt, B. A. (1998) Medieval English Women in Rural and Urban Domestic Space, Dunbarton Oaks Papers, 52, p. 19-29.

Heking, J. Fukoova arheologija, u: Mišel Fuko 1926-1984-2004, (prir.) Milenković, P. i Marinković, D. (2005a), Novi Sad: VSA, p. 129-141. 
J. Y. A. (1846/1847) Examples Of London Coffee-House And Tavern Tokens, The Numismatic Chronicle and Journal of the Numismatic Society 9, p. 49-66.

Janson, H. W. (1970) Istorija umetnosti, Beograd: Jugoslavija.

Johnson, S. (2009) A Meeting of Minds, RSA Journal, 155(5538), p.18-21.

Kant, I. (1783/2004) Odgovor na pitanje: šta je prosvećenost? Arhe, $1(1)$, p. $260-264$.

Кастан, Н. (2002) Јавно и појединачно, у: Историја приватног живота (3), Аријес, Ф. и Диби, Ж. (2002), Београд: Clio, стр. 364-390.

Klein, L. E. (1996) Coffeehouse Civility, 1660-1714: An Aspect of Post-Courtly Culture in England, Huntington Library Quarterly, 59(1), p. 30-51.

Koselleck, R. (1988) Critique and Crisis: Enlightenment and the pathogenesis of modern society. Cambridge, MA: The MIT Press.

Kümin, B. \& Tlusty, A. B. (2002) The World of the Tavern. The Public House in Early Modern Europe, Aldershot: Ashgate.

Le Gof, Ž. (2010) Da li je Evropa stvorena u srednjem veku, Beograd: Clio.

Lefebvre, H. (1997) The Production of Space, Oxford: Blackwell.

Lynn, A. M. (2001) Alcohol, Sex, and Gender in Late Medieval and Early Modern Europe, Basingstoke: Palgrave.

Manhajm, K. (1978) Ideologija i utopija, Beograd: Nolit.

Marinković, D. (2006) Konstrukcija društvene realnosti u sociologiji, Novi Sad: Prometej.

Marinković, D. Ideologija, javnost i rođenje ,trećih mesta”, u: Nacrt za sociologiju ideologije, Marinković, D. i Ristić, D. (2013), Novi Sad: Mediterran Publishing, str. 147-167.

Маринковић, Д., Шљукић, С. и Ристић, Д. (2014) Од генеалогије ка гео-епистемологији: заокрет ка локалности простора, времена и знања, Социолошки преглед, 48(3), стр. 333-352.

Мартен-Фижије, А. (2003) Ритуални обичаји у грађанској приватности, у: Историја приватног живота (4), Аријес, Ф. и Диби, Ж. (2002), Београд: Clio, стр. 152-210.

Minoa, Ž. (1994) Istorija starosti: od antike do renesanse. Novi Sad: Izdavačka knjižarnica Zorana Stojanovića.

Minoa, Ž. (2008) Istorija samoubistava, Novi Sad: Mediterran Publishing.

Niče, F. (1984) Vesela nauka, Beograd: Grafos. 
Oldenburg, R. (1989) The Great Good Place: café, coffee shops, community centers, beauty parlors, general stores, bars, hangouts and how they get you through the day, New York: Marlowe\&Company.

Paasi, A. (2001) Europe as a Social Process and Discourse: Considerations of Place, Boundaries and Identity, European Urban and Regional Studies, 8(1), p. 7-28.

Перо, М. (2003) Начини становања, у: Историја приватног живо$m a$ (4), Аријес, Ф. и Диби, Ж. (2002), Београд: Clio, стр. 245-260.

Philo, C. Foucault's geography, in: Thinking Space, (eds.) Crang, M. and Thrift, N. (2003), London: Routledge, p. 205-238.

Philo, C. (2005) Sex, life, death, geography: fragmentary remarks inspired by 'Foucault's populations Geographies', Population, Space and Place, 11 (4), p. 325-333.

Pincus, S. (1995) Coffee Politicians Does Create: Coffeehouses and Restoration Political Culture, The Journal of Modern History, 67 (4), p. $807-834$.

Renam, O. Utočišta intimnosti, u: Istorija privatnog života (3), Arijes, F. i Dibi, Ž. (2002), Beograd: Clio, str. 189-236.

Said, E. (2008) Orijentalizam, Beograd: XX vek.

Saunders, D. (1997) Anti-lawyers: Religion and the critics of law and state, London: Routledge.

Sennett, R. (1989) Nestanak javnog čovjeka, Zagreb: Naprijed.

Simmel, G. (1971) Sociability, in: Georg Simmel: On Individuality and Social Forms (Selected Writings), Levine Donald, N. (ed.), Chicago and London: University of Chicago Press, p. 127-140.

Simonsen, K. (2005) 'Bodies, sensations, space and time: the contribution from Henri Lefebvre', Geografiska Annaler: Series B, Human Geography, 87 (1), p. 1-14.

Stallybrass, P. and White, A. (1986) The Politics and Poetics of Transgression, Ithaca, New York: Cornell University Press.

Шартије, Р. Запис и његове примене, у: Историја приватног живота (3), Аријес, Ф. и Диби, Ж. (2002), Београд: Clio, стр. 100-142.

Todorov, C. (2010) Strah od varvara, Loznica: Karpos.

Veber, M. (2011) Protestantska etika i duh kapitalizma, Novi Sad: Mediterran Publishing.

Ven, P. (2014) Fuko: kao mislilac i kao čovek, Novi Sad: Mediterran Publishing.

Volton, A. (2016) Savršeni ribolovac, Novi Sad: Mediterran Publishing.

Zappiah, N. (2007) Coffeehouses and Culture, Huntington Library Quarterly, 70 (4), p. 671-677. 
Zimel, G. Georg Zimel 1858-2008, (prir.) Marinković, D. (2008), Novi Sad: Mediterran Publishing i VSA.

Dušan Marinković, Dušan Ristić and Lada Marinković

University in Novi Sad, Faculty of Philosophy, Novi Sad

THIRD PLACES:

GENEALOGY OF A HETEROTOPIA IN CIVIL SOCIETY

\begin{abstract}
The subject of research in this paper is coffee houses as third places. They are approached and defined from the sociological and the genealogical perspective. When observed as a spatialized history of places, genealogy provides an adequate theoretical and methodological framework for this research. The main task of such genealogy is to research the spatialization of a certain type of sociability and social capital in civil society. We have indicated broader social and historical circumstances in the genesis and development of third places as well as their contribution in the processes of developing a new type of sociability and public reasoning. The rise of coffee houses through history is contextualized: within the framework of a new type of critical public as opposed to the representative public; within the process of division between the private and public domain; as a kind of undifferentiated space/discontinuity/heterotopia that, in the social geography of the civil society, stands vis-à-vis the existing social stratums and the future spatial and class division. In conclusion we claim that, although the third places were privileged social spaces, they were not the only or fundamental places important for the genesis of rational discourse. However, third places were of key importance in the processes of forming urban institutes, development of public spaces, public speech, civil liberties and legitimacy of rationality in the societies of Western

Europe.
\end{abstract}

Key words: third places, coffee house, discourse, genealogy, heterotopia

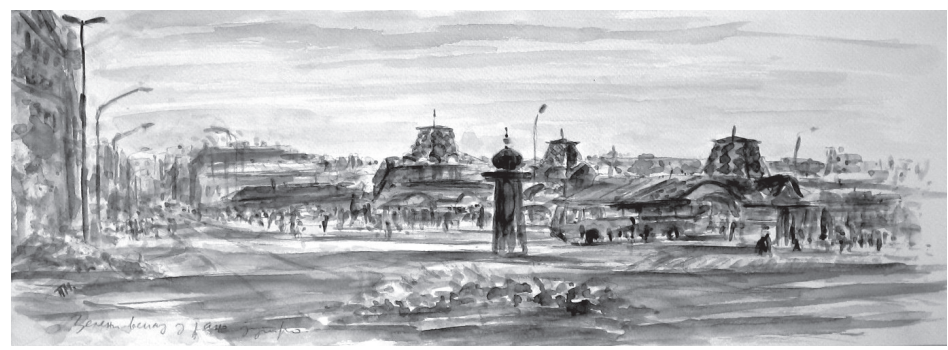

Миле В. Пајић, Рано јутро на Зеленом вениу 